Elena Ancuța ȘTEFAN

Faculty of Letters, "Ovidius" University

Constanța, Romania

anca.stefan19@gmail.com

\title{
TRAILS OF CULTURAL MEMORY: REDISCOVERING SHYLOCK AS A FATHER FIGURE IN THE $21^{\text {ST }}$ CENTURY
}

Recommended Citation: Ştefan, Elena Ancuța. "Trails of Cultural Memory: Rediscovering Shylock as a Father Figure in the $21^{\text {st }}$ Century”. Metacritic Journal for Comparative Studies and Theory 7.2 (2021). Doi: https://doi.org/10.24193/mjcst.2021.12.13

Abstract: Given that in the last few decades theories of adaptation have advanced enormously, with such names as Linda Hutcheon setting the theoretical premise of these ideas, it is essential to see how certain aspects present in canonical texts have been translated into present-day literature. In this paper, I discuss how the fatherdaughter relationship in The Merchant of Venice by William Shakespeare, has been (re)interpreted through the carrying of similar characters and situations in the novel Shylock Is My Name by Howard Jacobson. The novel does not only serve as a means of projecting old ideas as new, but it also provides the stage of resolution for such prominent characters as Shylock. In order to have a broader understanding of the (re)interpreted father-daughter relationship, this chapter will take into account the sociological symbolism of the contemporary text, with Erik Erikson's descriptions of adolescence in the foreground.

Keywords: Cultural Memory, father-daughter relationship, William Shakespeare, Shylock, Howard Jacobson.

"Shakespeare largely invented us" argues Harold Bloom in his work Anxiety of Influence, "[he] will not allow you to bury him, or escape him, or replace him" (Bloom xiii-xviii) and so does happen with some of the characters Shakespeare brought up on paper and stage; he gave people something to remember, to reference, to intertextualise. His characters became examples of behavioural patterns or 
proverbial illustrations. Such a persisting figure is Shylock, the Jew Merchant in The Merchant of Venice; a figure who, because of his multi-faceted nature, remains on the back of audiences minds long after the play is over.

Shakespeare's The Merchant of Venice has been adapted into a novel by Howard Jacobson, published in 2016 under the title Shylock is My Name and it only makes sense that he wrote this novel as a post-modern rewriting of Shakespeare's comedy. Jacobson is a Jewish writer and university professor, winner of the Man Booker Prize. However, the form is not the only thing adapted to fit our contemporary culture and likings, but the meanings of the play have also been reinterpreted to befit the readers of our time. Moreover, the novel pays a tribute to the bard's works that have been read, played and understood differently across centuries, by each generation.

The media through which the play's story is portrayed has an important role in understanding it; while a theatrical piece has to respect certain rules regarding the length and it also has to contain certain comical elements, in order to ease and appease the audience who expects to see a comedy, a novel can accommodate a longer story, with numerous meanings and even more groups of characters. A novel can solicit the reader's imagination forth, while the play, as a visual medium, can provide props and add to the spectators imagining of the story. Linda Hutcheon observes the advantages of the novel plots as compared to the dramatic plot, in her discussion about adaptation from drama to novel:

a shown dramatization cannot approximate the complicated verbal play of told poetry or the interlinking of description, narration, and explanation that is so easy for prose narrative to accomplish (Hutcheon 23).

Thus, as Linda Hutcheon argues in A Theory of Adaptation, while the novel's interpretation can be different for each and every reader, the play's way of delivery, through acting, leads to the audience having similar - or even the same understanding of the story.

In his novel, Jacobson focuses on Shylock, who is the marginalised character of The Merchant of Venice, while also keeping him in shadow as the action unfolds, but whose presence is felt in each key moment of the story. 
Such a rewriting project not only gives voice to the secondary character, but it also projects another side of the story and, by recounting it from another perspective, and essentially deconstructing it, there are unexplored meanings added to the new text. Therefore, while in the play there are perceptions of Shylock from each character's perspective, in the novel, that is the adaptation, the centrality of Shylock leaves no room for interpretation of the manipulative father image since this is the auctorial picture: the character who re-imagines the work.

\section{Father and Daughter in The Merchant of Venice}

The Merchant of Venice is a comedy by William Shakespeare, whose main focus is how people's identities can be misplaced and how things are not what they seem at a first sight. The main characters are Shylock, a Jew and his daughter, Jessica, who come into contact with Antonio, Bassanio, Lorenzo and Portia, among others. Being a Shakespearean comedy, by excellence, it must end well and so does this play: the good is rewarded, the bad is punished and justice is served.

Thus, being the receiver and giver of negative opinions throughout the play, "the very devil incarnation" (I.ii.24), as he is called by his servant Lancelet, Shylock the Jew is somehow exiled into his hatred, being denied any right of appeal or changing of mind; he is left to mourn not only his dead wife but also his rebellious daughter and his lost money; bitter, betrayed and lonely, he is laughed at, without anyone left at his side to see this man's suffering. Still, as Cedric Watts asserts, Shylock remains "a character so intense that he dominates the play" (Watts qtd. in Shakespeare, 2000, 9). Since he generates mixed reactions from the public - hatred, amusement, anxiety - there is no denial in the fact that, as Lorenzo tells Jessica, "the man that hath no music in himself" (V.i.83) would touch the heart and mind of anyone who follows his path through the play.

One of the most iconic scenes in the play is Shylock's running through the streets of Venice, in the second act, third scene, when he is shouting over his lost money and his daughter, who ran away with her lover, Lorenzo, who is a Christian:

I never heard a passion so confused,/ So strange, outrageous, and so variable,/ As the dog Jew did utter in the streets:/ 'My daughter! O my ducats! O my daughter!/ Fled with a Christian! O my Christian ducats!' (II.viii.12-16) 
However, the audience does not see this scene at first hand, but they hear it told by Solanio, who is, in fact, mocking the man's outburst, when he finds out about what Jessica has done. In this way, not only do the other characters during the dramatic interaction miss to understand Shylock's desperation caused by his daughter, but by seeing a secondhand account of the episode, given by Salarino and Solanio, the audience also fails to comprehend the gravity of the situation. Thus, nobody can perceive that Shylock is, in fact, a human being, whose character is more complex than what the two Christian onlookers want to describe. Shylock's actions are driven by a strong sense of self and deep-rooted Jewish principles, by which he stands, no matter how judgmental people are. Moreover, as described by Stephen Greenblatt, Shylock is mindful of the Christians ways, manners and reasoning against other groups of people, but he has a very strong sense of identity: "[Shylock] is not ignorant of their pleasures; he simply does not want any part of them" (Greenblatt 61).

Nevertheless, while religion is acted upon in an in-depth manner in studies about The Merchant of Venice, criticism of the play tends to treat parenthood as rather peripheral. Indeed, Shylock's daughter is about to marry a Christian man and the other characters in the play assume that she is nothing like her father. This is not only because Jessica denies her religious identity, but also because she appears to want to integrate and to let away any feeling of self-importance in order for her to belong to something other than her father's mercantile imperium.

Even more than this, it is obvious that she is afraid that her only features are attributed to her in connection to her father: she is Jessica, the Jew's daughter and therefore, by betraying her father, she redeems herself and seeks her own identity - a thing which Shylock is unable to see since his clear thinking is shadowed by the lost money and the lost ring. However, Jessica's act of selling the ring in exchange for a monkey is again her way of deconstructing and regaining herself.

Before Jessica exits, in the scene of her elopement with Lorenzo, it seems that she is indeed hurt by the fact that she has to go, but she also shows her need of escaping the isolation from her father's home: "Farewell; and if my fortune be not crost,/ I have a father, you a daughter, lost" (II.v.60-61). This statement implies that, in this father-daughter relationship, none of the two is able to see the other's 
torment: Shylock's anguish over losing whatever was most precious to him after his wife's death and Jessica's suffering over her inability to contour herself as her selfstanding persona.

Nonetheless, over time, critics have changed regarding Jessica's decision and attitude towards her father and Camille Slights even argues that "she must be a disloyal daughter in order to become a loving wife" and thus, Jessica's role in the play requires a dual interpretation, that is a young girl is on the verge of becoming a wedded woman (Slights 365).

In contrast, more recent responses to the play have criticized Shylock's fatherhood and have been less reproachful towards Jessica's actions. Contemporary readings of the play can attribute more negative features to Shylock's actions as a parent than to Jessica's response as a child. Janet Adelman argues, in her work of psychoanalytical criticism, Blood Relations: Christian and Jew in The Merchant of Venice, that Jessica runs away with Lorenzo out of desperation over her father's authoritative manner rather than only for the love of the man she is about to marry: "Lorenzo is invoked not as the solution to the problem of Jessica's erotic desire but as the solution to the problem of being her father's daughter" (Adelman 71). Thus, seeing that Jessica finds marriage to be the key to her freedom, then Shylock can be seen as a rather demanding and overprotective father, keeping his daughter at arm's length until she "collapses" (Adelman 71).

However, as Horacio Sierra points out, "Jessica's scant lines in the final scene mark her as an outsider" (Sierra 105); thus she will remain an outsider, an "other," even after the happy ending of the play, just because of her lineage, of her father, Shylock the Jew.

Read in this manner, the play portrays Shylock as a toxic father, ready to disavow his only relative alive that the audience knows of, because of his stubborn principles. Shylock does not see any possible reconciliation between himself and the people who have offended him and, therefore, he sees it impossible for his daughter to befriend those who despise him and who, in return, are despised by Shylock. As a father, he is driven by a sense of obedience and control that he expects to see from his daughter at all costs. This matter can be a result of Leah's death and the fact that 
he must take care of his daughter by himself, a daughter who is his only heir. Hence, he sees in Jessica his heritage, his name being led forward in time and his wealth being taken care of by a person whom he can trust no matter what. This is the reason for his going angry at his daughter's decision of running away with his money; Shylock feels that he is not in control anymore and that whatever he tried to build is on the verge of collapsing.

Thus, Shylock is the most persistent (father) figure, because he is infusing in the play both feelings of loathing and sympathy; loathing for everybody who hates him and sympathy for whatever is lost and cannot be repaired, such as, his wife's death and her memory, represented by the sold ring.

\section{Shylock versus Shylock}

In The Merchant of Venice, Shylock is asked by Portia, disguised as a lawyer, during the Court of Justice scene, about his name, to which, after a short break, the response is: "Shylock is my name" (IV.i.175). This line, this affirmation of identity, has endured throughout centuries up until the moment when Howard Jacobson wrote a novel, an adaptation of the play mentioned above. The title is most representative, because, during the trial scene, when the protector of justice, the lawyer, was himself a deceiver, Shylock, who wanted his justice, kept his head up and fully disclosed his identity, when, without shame or fakery, he tells everyone who wants to hear, who he is, namely that he is Shylock. By answering with his name fronted in bold letters, Shylock emphasizes it, making it sound even more astounding; throughout the novel, Shylock Is My Name, the re-interpreted Shylock will make his presence felt at all moments. Moreover, Jacobson uses these lines from the trial scene before the novel starts and, in this way, readers are reminded about what and who they are about to read:

Portia: Which is the merchant here, and which the Jew?/ Duke: Antonio and old Shylock, both stand forth./ Portia: Is your name Shylock?/ Shylock: Shylock is my name. (IV.i.174-75)

However, Shylock in the novel is not modernised or adapted to present times, but he is taken out of the play and put as such in the novel, since it is well known that the 
play offers different perspectives of the story, which are somehow comical, in comparison to the novel that gives Shylock the chance of speaking out his mind.

At the same time, Jacobson creates a character that has some of Shylock's psychological traits, such as the pain of his pride, the hatred and betrayal of his child, the loss of a partner in life, the shrewdness of asking what he cannot have, the frustration caused by all that is surrounding him, and that character is Simon Strulovitch. He is the twenty-first-century Shylock, a Jewish philanthropist with an eye for Anglo-Jewish art, having got divorced once, married a second time and being the father of a very rebellious daughter, named Beatrice. Just as Shylock, his presentday counterpart, Strulovitch, does not permit his daughter to marry a Christian man and in his rage, Strulovitch will end up with his daughter's running away, just as in the case of Shakespeare's Jessica.

Through intertextuality, Shylock is My Name includes other characters from The Merchant of Venice, besides the obvious presence of Shylock-Strulovitch and Jessica-Beatrice. (There is Plurabelle/Portia, D'Anton/Antonio, Banaby/Bassanio, Gratan/Lorenzo.) Almost all the characters seem to follow a certain pattern of stereotypes, which makes the action even more interesting since Jacobson switched the Shakespearean comic devices with his modern readers knowledge of societal standards, which are amusing and easily recognisable.

Amid all this fusion of transparency and simplicity that the novel's characters initially portray, there is Shylock, who seems to have transcended time and space and got to be an inhabitant of a contemporary postmodern British city that has long passed the Elizabethan and Jacobean times. Shylock appears as a shadow, more than anything, because he is not involved in the action of the novel, but has a persisting presence and a prominent role; he gives the impression of a symbolic figure of wisdom, almost like a philosopher with more life experience than any other character; he seems to be living more intensely within his mind, still together with his beloved Leah, and still betrayed by a long-gone daughter. The omniscient narrator describes the character's impetuous personality as follow:

Shylock, also an infuriated and tempestuous Jew, though his fury tends more to the sardonic than the mercurial, and the tempest subsides when he is able to enjoy the company of his wife Leah, buried deep beneath the snow (Jacobson, Shylock Is My Name 3). 
Jacobson kept Shylock's story in the novel, as well as his attributes, but he reinterpreted the character's attitude. Shylock is here more solemn in talk and manner, more secretive in his conversations with Simon Strulovitch. They become sort of partners or friends, after a rather odd encounter in a cemetery.

Furthermore, Shylock has a pivotal role throughout the novel; he not only adds a sense of solemnity to the action, but he also brings clarity among a group of people driven by wealth, power and seemingly nothing else but superficiality. It is even more ironic, comparing the novel to the play, that the same character that has been reviled and judged for centuries, and mocked for as much as that, is now an advocate of compassion and justice.

Another interesting aspect is the fact that Jacobson introduces Shylock's story as if it happened prior to the action of the novel. By pure insertion of a character, that is Shylock, Jacobson imitates Shakespeare, while also adapting the character's story as his own, in what Linda Hutcheon calls "the process of imitatio" (Hutcheon 20). In this manner, the reader can assume that, with Jacobson, Shylock goes through a symbolic freeing, because he has shown his true identity and his true feelings, only when the masks dictated by others are withdrawn and he is finally heard and understood. The secondary, the marginalised, the mocked achieve the well-deserved liberation and he becomes the auctorial figure in the story; he becomes Strulovitch's counsellor, helper in familial matters, even his call to reason.

Even more symbolical and paradoxical than this is the end of the novel, when, after delivering a speech about mercy (Jacobson, Shylock Is My Name 266), Shylock is approached by Plurabelle (the modern embodiment of Portia), who confesses her admiration for him: "that was awe-inspiring" (268) and asks Shylock if she could offer him anything, to which he answers with: "Peace and quiet are all I am in need of" (269). Moreover, Plurabelle admits that she did not believe that someone with Shylock's presence "could be capable of such humanity" (269). This remark leads to the two of them having a rather heated conversation about religion and the wrong judgements people can have because of one's faith, and Plurabelle feels cursed because of Shylock's forcefully manner of speaking. In this scene, Howard Jacobson himself states that: "I never saw it as my function to give Shylock a second chance. 
Where things ended for him, they end forever. But he does have one thing he would like to say to Portia/ Plurabelle. And I allow him to say it" (Jacobson, The Guardian). Thus, Shylock has the opportunity to clear things up with Portia, who is disguised as Plurabelle, regarding matters of justice and truth.

Shylock's last line in the novel is the most triumphant ending he could have: "Well now you know the sensation from the other end" (Jacobson, Shylock Is My Name 270). With this, he exits a different stage this time, a stage that gave him the chance to avenge himself, by using a most powerful weapon, that is, language.

\section{Father and Daughter in Shylock Is My Name}

Parenthood is one of the elements that has been translated from Shakespeare to Jacobson in a way that appears different and unchanged at the same time. There are traces of Shylock remembering his daughter, Jessica, but they play a secondary role and are meant more to be an example for Strulovitch and his relationship with his daughter, Beatrice. Besides the already mentioned similarities between Shylock and Strulovitch, in terms of ideas, temperament and demands from those around them, certain parallels can be drawn between Jessica and Beatrice, although their appearance in the play and the novel, respectively, are parted by so many centuries.

The first thing worth mentioning is the fact that both girls have overprotective fathers, to the extent that they dictate the people they can and cannot marry, being driven in their judgement by external factors, such as religion or position in society, rather than actual internal characteristics that the men towards whom their daughters have interest in may possess. Then, both Jessica and Beatrice are regarded as being rebellious and ungrateful to their fathers and their material situation, without the paternal figures taking into consideration the identity crisis the girls may face, due to isolation and inability of fitting in a larger group or circle. In his work Identity, Youth and Crisis, Erik Erikson argues that adolescence is a stage in which an individual is developing physically, but also mentally, through forming personal ideas about the world surrounding themselves, and this is why sometimes there may be a clash between generations, a bridge forming between parents and their teenage offspring, out of the need of the youth to express their free will (Erikson 129). Therefore, it can be observed how an adolescent girl like Beatrice may not feel comfortable under the tutelage of a strict father like Strulovitch. 
Jessica's and Beatrice's mothers are also meaningful; the extent to which the missing - fully or partially - of maternal figures led the girls to run away from home, since Jessica's mother, Leah, has passed away, and Beatrice's mother, Kay, has suffered a stroke, which made her incapable to take care of herself, let alone raising a child. Regarding Kay, Strulovitch feels guilty for what happened to her, since she had a stroke right after an argument between him and his daughter, the motive being Beatrice's going out with a boy he did not approve of, and what followed was that "he dragged Beatrice home by her hair. Shortly after that Kay felled" (Jacobson, Shylock Is My Name 143). In this manner, because of what happened to his wife and because he was left to supervise a teenage daughter amidst her identity crisis, Strulovitch thinks that the solution is to "keep Beatrice on the straight and narrow, to ensure that the high purpose he discerned in her delivery would be honoured" (142); thus he becomes the manipulative father figure, seemingly a mirror-image of Shylock.

This manipulative image of Strulovitch becomes so authoritative insomuch that he grows envious of Shylock after the former had a first encounter and a friendly discussion with Beatrice. Strulovitch comes to think that Shylock is trying to replace Jessica by appropriating Beatrice as his new daughter, a thing, which provoked his mind into having negative thoughts towards his guest:

All too impossibly Mephistophelean to imagine Shylock on an errand of this sort, Shylock here with the express purpose of replacing Jessica - no, surely not but it is deranging to lost a daughter as he had lost his and who's to say what derangement won't bring about? An eye for an eye, a daughter for a daughter (102103).

The final sentence is revealing of the Torah, in which such expressions are indicating of a pure idea of justice, but a justice that none of them has to serve the other; henceforth Strulovitch feels guilty for his thoughts, but he also excuses himself as being a normal thing for a father to be suspicious when he sees his daughter in the presence of another man (103). This attitude forced Strulovitch to ask Gratan, Beatrice's boyfriend, of converting to Judaism by means of circumcision if he is to be together with his daughter; the circumcision being the modern counterpart of the pound of flesh from The Merchant of Venice (30). The request is met reluctantly by both Gratan and also Beatrice, who decided to leave her father's house and, in one way or another, to run away from her incarcerator. 
In comparison with the play, and Jessica's barely explaining her decisions, the novel grants Beatrice to tell her side of the story. Jacobson lays emphasis not only on Strulovitch's justification of being rather harsh on his daughter but also on her reasoning of behaving reckless, up to the point where she leaves her home. After having heard what her father asked from Gratan, she flees her home together with her Christian lover, to Plurabelle's house - just as, in the play, Jessica leaves to Belmont, to Portia's house.

In the contemporary Belmont villa, while contemplating on her existence and especially on her relationship with her father, Beatrice reveals everything she had to go through because of him: "My whole life, she thought, has been made a misery by him" (167). Her suffering was mostly caused by the social humiliation her father put her through. However, Beatrice is aware of Strulovitch's recurrent presence in her life and of his wanting the best for her, although he seems to be causing even more confusion and mixed feelings in her mind. Thus, Strulovitch can be seen not only as a paternal but also as a patriarchal figure in her life, a persistent figure, to whom she is not able to turn her back completely: "She couldn't fall in love with anyone else. (...) she could think only of her father" (168). This father-daughter relationship appears to have traces of what C. G. Jung calls "the Electra complex", although Beatrice does not seem to be competing with her mother, on the contrary, she would like to have her mother around more. However, going back to Erikson's theories regarding the stage of adolescence, he argues that this is what a teenager feels: "that the environment tries to deprive him too radically of all the forms of expression which permit him to develop and integrate"; then he or she will look for ways of resisting and fighting back, sensing the same amount of emotion as an animal in need of protecting itself (Erikson 130).

In addition, on the matter of adolescence and love, Erik Erikson argues:

To a considerable extent, adolescent love is an attempt to arrive at a definition of one's identity by projecting one's diffused self-image on another and by seeing it thus reflected and gradually clarified. This is why so much of young love is conversation (Erikson 132). 
Thus, Beatrice is not only projecting her want of identity and security on Gratan, but she also wants to feel that she belongs to something or someone, because a sense of belonging brings comfort to individuals. This is why, when the two leave for Venice, Beatrice ponders once again upon her decision and upon her relationship with Gratan, which suddenly for her, does not seem as satisfying as she expected, insomuch that she even wonders why she did run away with him in the first place: "Oy, vey, why have I run away?" (Jacobson Shylock Is My Name 208). As any young girl at the age of becoming, she has great expectations, especially when it comes to the people or to the person she puts all her trust into. This is why, when she realises that other than the carnal component, their relationship does not present any other feature of substantial matter, Beatrice becomes despondent and conscious of her own decision making, a thing which is another step towards her development as a future mature woman.

The novel concludes the father-daughter relationship between Beatrice and Strulovitch with their meeting again after her and Gratan's returning from Venice. Both father and daughter exchange pleasantries, in the presence of Kay, with Beatrice being quite harsh on his father, by saying: "I'm unharmed (...) And unbetrothed, if that's what you really want to know" (277). On the other side, Strulovitch seems to be at ease that his daughter is back home, thinking that it is unfair that she had to go through all this suffering; although in manner and speech Beatrice seems to be more mature than at the beginning of the novel, her father still sees her as a child. However, contradictory to his thinking of his daughter in terms of the child-like features she may still have, he admits that "in her stony unforgivingness she resembles Shylock" (277), which is a peculiar thing to say, but this only proves that Beatrice never wanted to shed away her father's lineage, nor her Jewish heritage, but she wanted her freedom from her father's grasp, her own fullyfledged identity.

Moreover, the last sentence of the novel is revelatory of the father-daughter relationship in both The Merchant of Venice and Shylock Is My Name: "I will be revenged on the whole pack of you" (277). This sentence, intertextualised from the fifth Act, first Scene of the play Twelfth Night, is now in Strulovitch's mind, a thing which can have a double meaning, since the character who first uttered this sentence, 
namely, Malvolio, is an antagonistic character, who is representative for the idea of contempt, when everybody else is joyous, just as Shylock at the end of The Merchant of Venice or Strulovitch at the end of the novel. A first interpretation of this final sentence could be that Shylock is finally avenged by Beatrice, since this strong-willed girl has something in common with Shylock, that is the unforgiveness Strulovitch mentioned, a thing which can signal that Jacobson found Shylock an heir in the embodiment of an adolescent girl, although she is born decades later from Shylock's first appearance on stage. The second meaning of this same sentence can refer to Strulovitch, who after being made fun of, has his daughter back and can only hope that she will somehow give him justice, if only through her having bitter ideas about the world, just like her father.

\section{Conclusion}

While both The Merchant of Venice and Shylock Is My Name raise questions of religion, group identity and societal flaws, an aspect that cannot be left apart is parenthood. Both texts posit the father-daughter relationship in the foreground, although the time span between the two is quite enormous. Nonetheless, common elements are present in both Shakespeare's representation of the Shylock-Jessica characters and Jacobson's picture of Strulovitch-Beatrice, with the latter being given a wider array of expression, due to its medium. Thus, regarding the media and genre of each text, it is commonsensically believed that a play will also provide a comical side, besides its positing meaningful questions, because of its performativity, while the novel, being composed mostly of narration, will leave space for deeper insights into the character's mind, with the reader being able to better understand their reasoning into decision making. Furthermore, the daughters in the play and the novel reflect the issue of parenthood and family similarly and differently, according to each of their contexts.

While in the play, family is a dialogic issue that involves the focus on the theatrical performance of dramatic characters, such as Shylock, then in the novel, the same character is represented in its complexity, with various other forms and ideas, having interactions with the family in focus formed by Beatrice, the daughter, Simon Strulovitch, the father and a mother, Kay, which although she may seem absent throughout the novel, seems to be the binding force that brought father and daughter 
back together in the end. Finally, while Jessica's character is somehow shadowed by her father and the triangle Antonio-Bassanio-Lorenzo, in Jacobson, the substance of the character Beatrice is given by a complex identity; although she is a teenager, she has second thoughts, deep-rooted familial feelings and a taste for art, which can be rather uncommon for a teenage girl, but which are features adopted from her father's side.

Shylock is, without any doubt, the model by which Strulovitch is constructed; they both permeate their origin texts, being extremely present throughout the action, with Shylock's multi-faceted and performative discourses being memorable through their fierceness of delivery in The Merchant of Venice. By means of insertion in Shylock Is My Name, the character Shylock, in its entire complexity, is used to compel and somehow manipulate each character with his mysterious presence and ambiguous manners of acting and talking. He becomes the genius behind the machine, who puts in motion the action; he is the voice of reason, who seems, at times, to have an experience of life as old as the play. In this manner, with Howard Jacobson's aid, Shylock is allowed to recover himself and to show his complex nature in a contemporary setting, proving his relevance even after four centuries since he first appeared on a stage.

\section{References:}

Adelman, Janet. Blood Relations: Christian and Jew in The Merchant of Venice. The University of Chicago Press, 2008.

Bloom, Harold. The Anxiety of Influence: A Theory of Poetry. Oxford University Press, 1997.

Eriksson, Erik. Identity, Youth and Crisis. W. W. Norton \& Company, 1968.

Greenblatt, Stephen. Shakespeare's Freedom. The University of Chicago Press, 2010. Hutcheon, Linda. A Theory of Adaptation. Routledge, 2006.

Jacobson, Howard. "Villain or victim, Shakespeare's Shylock is a character to $\begin{array}{lllllll}\text { celebrate." The Guardian. } & 05 & 02 & 2016 . & 10 & 02 & 2020 .\end{array}$ $<$ https://www.theguardian.com/books/2016/feb/05/villain-victim-shylockshakespeare-howard-jacobson>.

Jacobson, Howards. Shylock Is My Name. Penguin Random House, 2016. 
Jung, C. G., Jung Contra Freud: The 1912 New York Lectures on the Theory of Psychoanalysis. Princeton University Press, 1961.

Shakespeare, William. The Merchant of Venice. Edited by Cedric Watts Hertfordshire, Wordsworth Classics, 2000.

Sierra, Horacio. "I Make It Breed As Fast": Paternal and Financial Anxiety in The Merchant of Venice." New Readings of "The Merchant of Venice". Edited by Sierra, Horacio, Cambridge Scholars Publishing, 2013, pp. 85-107.

Slights, Camille. "In Defense of Jessica: The Runaway Daughter in The Merchant of Venice." Shakespeare Quarterly vol. 31, no. 3, 1980, pp. 357-368.

Watts, Cedric. "Introduction." Shakespeare, William. The Merchant of Venice. Wordsworth Classics, 2000, pp. 9-21. 